\title{
Graublaue Ausschau
}

Himmelsfarbe graues Blau spiegelt sich im See genau, hält dem Schiff die Wege offen wie für mich im weiten Hoffen.

Farbe gänzlich ungeschminkt, See zum Himmel steigend sinkt, ganz als ob die Atmosphäre Spiegel nur für Lichtes wäre.

Wie wenn Kindheit nochmals würde löst der Glanz des Grauens Bürde, wo im Horizont vereint, Fremdes als ein Freund erscheint.
Hält sich kurze Zeiten lang wie ein stiller Übergang, wo die Bäume grau verrauchen, scheinbar keine Farbe brauchen.

Dieses Grau ist sogar schlank, diese Wintertage jung: bleibt so in Erinnerung einziges Gefühl ist: Dank!

\section{Jürg Kesselring, Valens}

